\title{
Housewives, Slaves, and Indigenous Peoples: Hybridity in the Diet of the American Frontier
}

\section{Duncan Smith}

The United States is often described as a metaphorical "melting pot." Many Americans pride themselves on living in a multicultural country, a characteristic which can be traced back to the colonial era. However, the melting pot nature of colonial United States emerged not from a celebration of diversity, but from assimilation and proselytism in the interests of missionary efforts, indentured servitude, and enslavement. For better or for worse, this hybridization - the ongoing blending of culture - reverberates throughout all aspects of the American identity. One especially fascinating realm is cuisine. "American food," as it is interpreted today, was formed during the $18^{\text {th }}$ to mid- $19^{\text {th }}$ centuries as a synthesis of multiple cultures of the frontier. The European settlers, the Indigenous tribes, and the African slaves were the main players in this process of acculturation. The influx of European immigrants and African slaves during the colonial era led to the introduction of new cooking styles and ingredients that blended with local Indigenous culinary practices. A major portion of the body of sources for this research paper is comprised of cookbooks from the 1700 s to the mid-1800s, which provides the basis for a broader analysis of trends. One key trend that is particularly relevant to the domain of cooking is the role of women in society. An overwhelming majority of culinary-focused primary documents are penned by female authors, allowing for an analysis of the dietary habits on the frontier not only ethno-culturally, but also from a female perspective. These sources shed light on the status of women and the relative autonomy they had in colonial society: the emerging American "foodways" led to dynamic shifts in their agency and social mobility over time, and moreover women were driving forces in hybridity itself. As a whole, American cooking reflects the 
nation's history. Thus, a close examination of dietary habits can demonstrate what defined daily living for historically disenfranchised groups such as women, Indigenous Americans, and slaves. In sum, the American culinary habits were transformed throughout the colonial period due to the contributions of these cultural forebears. This hybridization of dishes and cooking methods formed the basis of American cuisine and is a defining factor of the United States' dietary identity.

While an extensive body of academic literature has been written on the topic of colonial America, the topic of food could benefit from more attention from scholars. Nonetheless, there exist numerous strong academic works on the food history of this era. One example is $A$ Revolution in Eating by James E. McWilliams, Professor of History at Texas State University. It is notable as it attributes food as a primary factor in shaping American identity, creating a thorough framework for analyzing the impact of slave and Indigenous populations. While this work provides effective historical analysis of the exchange of food traditions between the Indigenous Americans and the European colonists, its focal point heavily leans toward the male experience. In contrast, this paper will be approaching the topic of dietary hybridity from the angle of the female experience. In general, many secondary sources on this subject thoroughly examine the relationship between European culture and the Native American communities, but less attention is explicitly given to women. Eat my Words: reading women's lives through the cookbooks they wrote, written by Janet Theophano, is a strong example of a social history which specifically aims to include the female voice. A detailed analysis of primary sources, it weaves an extensive narrative of women's lives in the colonial period. Sources such as Eat my Words are especially pertinent to this area of research as they provide synthesis of relevant material as well as interpretation from an important and often neglected angle. 
As the selected readings undoubtedly reveal, the Indigenous-European cultural exchange was a seminal part of food culture on the American frontier. In the earlier years of colonization, settlers brought with them a wide range of resources unfamiliar to the New World. Honeybees, ${ }^{1}$ grains and breads, ${ }^{2}$ vegetables, ${ }^{3}$ and fruit were brought early on by the English, Dutch, and Spanish. ${ }^{4}$ Many of these resources would become later incorporated into the Indigenous tribes' daily consumption and agricultural practices. ${ }^{5}$ Sugar is one of the crops that had the most profound impact on the New World. Along with tobacco, rice, and cotton, sugar was a driving force in colonial society. The increasing production of sugar forever altered the experience of the Indigenous civilizations, their agriculture, and the ecology of the land itself. ${ }^{6}$ It was a driving force in hybridity: as historian Elizabeth Abbott notes, it opened a "triangular trade" between Europe, Africa, and North America, arguably the three biggest players in American cuisine. ${ }^{7}$ This resulted in new "Creole" societies, which would form their own unique regional flavours. Initially, European colonists aimed to reproduce their traditional diets in the New World. ${ }^{8}$ Explorers as early as Columbus had noted how the New World was abundant in fowl and fish, but had little in the way of livestock animals. ${ }^{9}$ In an early effort to reproduce the diets of the Old World, settlers imported animals such as pigs, cows, sheep, horses, and chickens. ${ }^{10}$ Indigenous villages eventually incorporated poultry, beef, and pork, among other new meats into their diet by the mid- $18^{\text {th }}$ century. ${ }^{11}$ These animals immensely changed the Indigenous peoples' ways of

\footnotetext{
${ }^{1}$ Colin G. Calloway, New Worlds for All (Baltimore: The John Hopkins University Press, 2013), 13-14.

${ }^{2}$ Ibid, 57.

${ }^{3}$ Ibid, 13-14.

${ }^{4}$ Ibid, 57.

${ }^{5}$ Ibid.

${ }^{6}$ Elizabeth Abbott, Sugar: A Bittersweet History (Toronto: The Penguin Group, 2008), 26.

${ }^{7}$ Ibid, 27.

${ }^{8}$ Giovanni Rebora, Culture of the Fork (New York: Columbia University Press, 2001), 132.

${ }^{9}$ Ibid, 130.

${ }^{10} \mathrm{Ibid}, 132$.

${ }^{11}$ Calloway, New Worlds for All, 57.
} 
life. Animals were now seen as property to be traded, which altered the spiritual traditions of hunting. ${ }^{12}$ Due to a growing demand for red meat, ${ }^{13}$ Indigenous peoples began to participate in the slaughter of animals - animals with which they had once shared a spiritual kinship - on an unprecedented scale. ${ }^{14}$ For many thousands of years, the Indigenous tribes had treated animals with respect, only taking what they needed. After the colonization of the New World, it became commonplace to treat game and fish as mere commodities. Moreover, horses revolutionized transportation and hunting on the frontier, ${ }^{15}$ drastically shifting the buffalo-hunting dynamic and driving the herds of the Great Plains to near-extinction. ${ }^{16}$

While the Europeans introduced a variety of new foodstuffs from overseas, Indigenous Americans were well versed in bartering and had a long tradition of trading, so they too offered new resources to the settlers. ${ }^{17}$ One crop that is almost omnipresent throughout the colonial cultural exchange is maize, or "Indian corn." ${ }^{18}$ Historian James E. McWilliams proposes that there is "no food more symbolic of this cultural interaction [between the Old and New World] than Indian corn." 19 It was not initially popular among the colonists, however, as many had a prejudice against consuming this crop: it was seen as no more than "swine food." 20 After the initial reluctance wore off - due to its nutritional value, high yields, and versatility - it quickly became a highly ubiquitous national staple, ${ }^{21}$ often used to provision the armies of the

\footnotetext{
12 Ibid, 14.

${ }^{13}$ James E. McWilliams, A Revolution in Eating: How the Quest for Food Shaped America (New York: Columbia University Press, 2005), 80-81.

${ }^{14}$ Calloway, New Worlds for All, 15-16.

15 Ibid, 14.

${ }^{16}$ Ibid, 58-59. For a primary source detailing the buffalo extinction, see J. M. Baltimore, "In the Prime of the Buffalo," Overland monthly and Out West magazine, November 1889, 515.

${ }^{17}$ McWilliams, A Revolution in Eating, 138.

${ }^{18}$ Calloway, New Worlds for All, 52.

${ }^{19}$ McWilliams, A Revolution in Eating, 8.

${ }^{20}$ McWilliams, A Revolution in Eating, 55.

${ }^{21}$ Calloway, New Worlds for All, 52.
} 
colonies. $^{22}$ This reveals that while the settlers' diet was often impacted by European "fashionability," 23 the acceptance of unfamiliar foods was ultimately driven by necessity. Maize also had ritualistic use for the Indigenous Americans as a member of the three "Sacred Sisters."24 Alongside beans and squash, the "sisters" were the three main crops of many Indigenous American groups. The Indigenous people taught settlers to cook these three crops into a dish called succotash. Popular in the winter, ${ }^{25}$ this hearty stew displays the influence of Indigenous tradition on settlers' diets. ${ }^{26}$ Broadly speaking, the diet of the American Indigenous people was a combination of hunting and gathering, as well as some farming. ${ }^{27}$

With immense knowledge of the land and intricate, time-tested cycles of hunting and agriculture, Indigenous Americans had much to share. ${ }^{28}$ They taught settlers how to hunt and fish in the New World, and many colonies became reliant on local Indigenous communities for supplies well into the eighteenth century. ${ }^{29}$ The European settlers had heavily incorporated Indigenous hunting techniques into their lives, particularly in the backcountry. ${ }^{30}$ The result was a cultural blending, which led missionary David McClure to remark that backcountry settlers were essentially "white savages" who "live like the Indians." ${ }^{31}$ Despite their similarities, the European hunters in the backcountry lacked the Indigenous ethic of kinship and ritual in hunting, and did not typically respect the traditions of tribes. ${ }^{32}$ In terms of farming, many Indigenous agricultural

\footnotetext{
${ }^{22}$ Ibid, 53.

${ }^{23}$ Ibid, 54 .

${ }^{24}$ Ibid, 52.

${ }^{25}$ Mrs. N. Orr, De Witt's Connecticut Cook Book and Housekeeper's Assistant, (New York: Robert M. De Witt, 1871), 57.

${ }^{26}$ Calloway, New Worlds for All, 53.

${ }^{27} \mathrm{McW}$ illiams, A Revolution in Eating, 59.

${ }^{28}$ Ibid, 138.

${ }^{29}$ Calloway, New Worlds for All, 55-56.

${ }^{30}$ Ibid.

${ }^{31}$ David McClure, Diary of David McClure, doctor of divinity (New York: The Knickerbocker Press, 1899), 93.

${ }^{32}$ Calloway, New Worlds for All, 56-57.
} 
and livestock-tending practices went on to become the standard practice in regions such as the Carolinas. ${ }^{33}$ Indigenous peoples taught the settlers how and when to plant corn and how to harvest, preserve and cook it. ${ }^{34}$ This demonstrates the extent of the settlers' reliance on the Indigenous peoples, further illustrating how cultural borrowing was often a matter of basic necessity and survival.

Early colonial society was characterized by plenitude: the abundance of untapped natural resources formed the foundation for American cuisine. ${ }^{35}$ Production and distribution of food was a primary concern on the frontier, and the relationship with food resources in early America was very "hands-on." ${ }^{36}$ McWilliams makes the case that American cookery is rooted in the "roughness" of the frontier conditions. ${ }^{37}$ Settlers had no other option but to become selfsufficient in their food production, which fostered a much more intimate relationship with their food in comparison to Europe. ${ }^{38}$ This particularly gave women a newfound sense of importance within society: food had become a very powerful force, and much of this power was invested in the housewife, who had dominance over household affairs such as procuring meals. ${ }^{39}$ This is reflected in early cookbooks. For example, Mary Randolph, author of The Virginia Housewife, asserts a distinct sense of control to the housewife. She writes that the "prosperity and happiness" of a family are dependent on the wife's exemplary performance of her duties. ${ }^{40}$ In Lillian Schlissel's Women's Diaries of the Westward Journey, she observes that it was often the women

\footnotetext{
${ }^{33}$ McWilliams, A Revolution in Eating, 150.

${ }^{34}$ Calloway, New Worlds for All, 53.

${ }^{35}$ McWilliams, A Revolution in Eating, 7.

${ }^{36}$ Steven M. Tobias, "Early American Cookbooks as Cultural Artifacts," Papers on Language \& Literature 34.1, (Carbondale: Southern Illinois University Press), 3.

${ }^{37}$ McWilliams, A Revolution in Eating, 6-7.

38 Ibid.

39 Tobias, "Early American Cookbooks," 3.

${ }^{40}$ Mary Randolph, The Virginia Housewife: or, Methodical Cook, (Baltimore: John Plaskitt, 1836), xii.
} 
who played the crucial task of bartering with Indigenous people for food on the trail. ${ }^{41}$ In times of hardship and social restriction, white housewives as well as black slave women expressed unique strength, wisdom, and creativity in the kitchen. Author John Egerton argues that the kitchen was one of the few domains where "their imagination and skill could have free rein and full expression[...]." ${ }^{42}$ A group called the Daughters of Liberty, formed during the American Revolution, exemplified colonial women's use of domesticity as an instrument of power. These women were glorified for creating homemade goods as a boycott against the British, using their household roles to take part in the revolution. ${ }^{43}$ They were active in the formation of the American identity, not only playing a lead role in the emerging food culture, but also bolstering the revolutionary ideals that set the United States apart from their mother country in the first place. Despite their relative lack of social mobility, women were not a monolithic group of passive victims: they were powerful historical actors that expressed their agency in many unique ways. Food and domestic roles are just one of their numerous outlets to express autonomy.

During the $18^{\text {th }}$ century, American cuisine was comprised of what Historian James E. McWilliams calls a "patchwork" of regional diets. ${ }^{44}$ The culinary model of the time was not rigid, but was, writes McWilliams, "a compromised negotiation of traditional habits." 45 This "patchwork" would eventually develop into a unified dietary identity. Central to this development, McWilliams argues, was the widespread usage of imported utensils and cookbooks; uniformity in the frontier kitchen was a catalyst for the convergence of these regional cooking habits. ${ }^{46}$ This notion can be extended and applied to the female experience. These

\footnotetext{
${ }^{41}$ Lillian Schlissel, Women's Diaries of the Westward Journey, (New York: Schocken Books, 2004), 53.

${ }^{42}$ John Egerton, Southern Food: At Home, on the Road, in History, (Chapel Hill: The University of North Carolina Press), 15.

${ }^{43}$ Eric Foner, Give Me Liberty! An American History, (New York: W. W. Norton \& Company, 2008), 184.

${ }^{44}$ McWilliams, A Revolution in Eating, 13.

${ }^{45}$ Ibid.

${ }^{46}$. Ibid, 14.
} 
imported goods created a consistent 'toolbox' for housewives across America, and the widespread popularity of some cookbooks over others encouraged a more unified approach to cooking. The case could be made that the convergence of regional cooking styles into a broader American food culture was driven by women and their arsenal of kitchen technology and cookbooks. The result is a mosaic of various ingredients, dishes, and food-based traditions from a variety of cultural backgrounds. While it borrows extensively from its cultural progenitors, this cuisine is also distinctly American and plays a major role in the national identity of the United States. For example, Thanksgiving, a holiday very deeply ingrained in American cultural mythos, provides an excellent case study of dietary hybridity. ${ }^{47}$ A synthesis of foods from both worlds, the archetypal Thanksgiving dinner consists of ingredients familiar to the Indigenous Americans adopted and prepared in very European ways. For example, American turkey prepared as an English celebratory roast, indigenous pumpkins made into European-style pies, and a cornucopia of native corn and squash. ${ }^{48}$

The colonies of the New World were forming their own identifiable food culture, drawing from familiar food traditions from Europe whilst integrating resources and traditions from the Indigenous peoples. Another hybrid dish was Boston Baked Beans,${ }^{49}$ which was sweetened with molasses, a New World sweetener. ${ }^{50}$ Mrs. Owen advises the reader of her cookbook: "Do not forget the sweetening, or you will not have Yankee baked beans." ${ }^{51}$ Owen demonstrates a growing awareness of the unique American culinary identity and a sense of pride about what makes it distinct. Another staple recipe, "Indian Pudding" (or "Mush"), took the form

\footnotetext{
${ }^{47}$ Calloway, New Worlds for All, 53.

${ }^{48}$ Evadene A. Burris, "Frontier Food," Minnesota History 14, (St. Paul: Minnesota Historical Society Press, 1933), 391.

${ }^{49}$ Calloway, New Worlds for All, 53.

${ }^{50}$ Abbott, Sugar, 353.

${ }^{51}$ Mrs. T. J. V. Owen, Mrs. Owen's Illinois Cook Book, (Springfield: John H. Johnson, 1871), 106.
} 
of a grainy corn-based porridge. ${ }^{52}$ It is likely a derivative of the English "Hasty Pudding," prepared in an "Indian" style. ${ }^{53}$ This dish too remains a part of the United States' identity, and was even mentioned in the patriotic tune Yankee Doodle.

In the South, where slavery was deeply entrenched, food tradition was built upon the economic foundation of slave-grown crops such as corn and rice. Sarah Rutledge acknowledges the prevalence of these ingredients in the preface of The Carolina Housewife, stating: "In this work are to be found about a hundred dishes in which rice or corn forms a part of the ingredients. ${ }^{\prime 54}$ Food culture of the Deep South was shaped by the three forces of European (mainly British and French), Indigenous American, and African slave traditions. Southern culinary expert John Egerton argues that the $18^{\text {th }}$ and $19^{\text {th }}$ centuries were a time period at which the "hospitality and cuisine of the South reached its apex." ${ }^{55}$ Southern women had an important, yet perhaps understated, role in this culture. Women were the primary authority over the domain of cooking in the South, despite their perceived lack of autonomy within the southern culture of honour. Cooking was a way for many southern women to express themselves. ${ }^{56}$ The Virginia Housewife exemplifies many core dishes in the Southern food tradition: barbequed pork, ${ }^{57}$ fried chicken ${ }^{58}$ sweet potato,${ }^{59}$ and gumbo. ${ }^{60}$ Gumbo was a highly acculturated dish, borrowing the French technique of roux, using Sassafras from Choctaw tribes and West African Okra. ${ }^{61}$

Southern food grew popular throughout the United States as a whole, as there is evidence of

\footnotetext{
${ }_{52}$ Maria Parloa, The Appledore Cook Book, (Boston: Andrew F. Graves, 1880), 112.

${ }^{53}$ Eliza Leslie, Miss Leslie's New Cookery Book, (Philadelphia: T. B. Peterson and Brothers, 1857), 412-415.

${ }^{54}$ Sarah Rutledge, The Carolina Housewife: or, House and Home, (Charleston: W. R. Babcock, 1851), iii-iv.

${ }_{55}^{55}$ Egerton, Southern Food, 15.

${ }^{56}$ Ibid.

${ }^{57}$ Randolph, The Virginia Housewife, 51-52.

${ }^{58}$ Ibid, 75-76.

${ }^{59}$ Ibid, 108-109. For similar recipes, see Mrs. Lettice Bryan, The Kentucky Housewife, (Cincinnati: Shepard \& Stearns, 1839), 199-200.

${ }^{60}$ Randolph, The Virginia Housewife, 81.

${ }^{61}$ McWilliams, A Revolution in Eating, 125.
} 
Southern recipes travelling north; in Miss Beecher's domestic receipt book, there is a recipe for Corn Muffins "from the South," 62 even though she wrote the book while living in Ohio. This reveals that dietary habits and "foodways" were spreading throughout the colonies, contributing to America's gradual unification toward a common dietary identity.

On the cusp of the Civil War, the concept of femininity was beginning to shift, as women needed to take on the labour once performed by slaves. ${ }^{63}$ While in many ways their domestic abilities allowed them to express autonomy, Schlissel examines ways in which these duties could also be a major burden for women: their responsibilities were expanded, but not their decisionmaking power. ${ }^{64}$ At this point in the United States' history, most of the cookbooks in this bibliography were beginning to be published by housewives across the nation. One of the most prominent recipe books was Amelia Simmons' American Cookery, the first published American cookbook. This monumental work was the first time the American "culinary voice" was expressed widespread in print. ${ }^{65}$ Described as a "culinary declaration of independence," ${ }^{66}$ its preface - directed at a "rising generation of females" - promoted the increasingly egalitarian values of the new American republic. ${ }^{67}$ Through the language of recipes, Simmons formed a link between cuisine and patriotism in the national consciousness. ${ }^{68}$ Moreover, Janet Theophano notes that it was the first cookbook to encourage hybridity by presenting adaptations of English recipes using New World ingredients. ${ }^{69}$ For example, Simmons adapts British puddings with

\footnotetext{
${ }^{62}$ Catharine Esther Beecher, Miss Beecher's Domestic Receipt Book, (New York: Harper \& Brothers, 1846), 99.

${ }^{63}$ Janet Theophano, Eat My Words: Reading Women's Lives through the Cookbooks They Wrote, (New York: Palgrave, 2002), 54.

${ }^{64}$ Schlissel, Women's Diaries, 64.

${ }^{65}$ Theophano, Eat My Words, 233.

${ }^{66}$ Jan Longone, "Amelia Simmons and the First American Cookbook," American Bookseller, (1996): 449.

${ }^{67}$ Amelia Simmons, American Cookery, (Albany: Charles R. \& George Webster, 1796), 3.

${ }^{68}$ Theophano, Eat My Words, 233.

${ }^{69}$ Ibid, 234.
} 
native ingredients such as winter squash. ${ }^{70}$ Interestingly, Simmons alters the names of Old World dishes, adjusted to fit the new cultural climate, such as "Independence Cake." ${ }^{71}$ All in all, this prominent publication resonated with less-privileged women, allowing them to test the boundaries of a housewife's authority. ${ }^{72}$

Women could explore their own identities, and in turn (though perhaps unknowingly) shape a broader identity of their national as a whole. Women also had a newfound sense of convenience, no longer needing to rely on memory and oral transmission. ${ }^{73}$ This allowed for the quicker and more far-reaching spread of recipes and culinary knowledge. Moreover, publishing cookbooks gave a new sense of duty to many housewives. Despite her marginalized social position as a woman and self-proclaimed "American Orphan," Amelia Simmons claims authority and deep cultural knowledge through her cooking skills. ${ }^{74}$ Mary Randolph promotes helping the next generation in the introduction to her cookbook, ${ }^{75}$ and Owen too emphasizes the idea of guiding a younger generation of women. ${ }^{76}$ Lettice Bryan presents the role of a cook and housewife as one of major importance. ${ }^{77}$ She writes with authority and first-hand experience, asserting to her female readers in the introduction that "very much depends on your own conduct and management, to secure to yourself and family happy, and peaceful lives." ${ }^{78}$ Another author, Maria Parloa, confidently states that the masses need culinary guidance and she feels "competent to supply them" with recipes. ${ }^{79}$ Yet, one should not overestimate women's freedom; in general

\footnotetext{
${ }^{70}$ Simmons, American Cookery, 34.

71 Theophano, Eat My Words, 235.

72 Ibid, 241.

73 Tobias, "Early American Cookbooks," 3.

74 Theophano, Eat My Words, 235.

${ }^{75}$ Randolph, The Virginia Housewife xi-xii.

${ }^{76}$ Owen, Illinois Cook Book, v.

${ }^{77}$ Bryan, The Kentucky Housewife, vii.

78 Ibid.

${ }^{79}$ Parloa, The Appledore Cook Book, 3.
} 
they were still very limited in society due to their gender, from a legislative and cultural standpoint. These cookbooks can, along with messages of empowerment, contain traces of these deeply-ingrained cultural norms and barriers that prevented women from achieving full equal status.

Domestic skills were the criteria for judging a "good" woman; broadly speaking, a woman's success was contingent on how well "behaved" she was in a domestic setting. ${ }^{80}$ Randolph illustrates this notion, insisting that effective management of domestic affairs is crucial to a woman of "good sense." ${ }^{81}$ Bryan's introduction reflects the expectations of a Southern lady: to be a model of "loveliness and true elegance" and to make her husband "proud and happy" knowing that he is "in possession" of a dutiful housewife. ${ }^{82}$ Yet, all things considered, even the most socially conservative female writers - who explicitly or implicitly promoted the restriction of women - in the very act of writing and publishing a cookbook broke the gender norms of an era where women were discouraged from engaging in the public sphere. ${ }^{83}$ Evidently, colonial women's domestic expertise was a double-edged sword when it comes to their autonomy. By and large, however, great strides toward women's societal and civil freedom were occurring all over the United States; cooking was simply one of the many areas in which this trend can be detected.

In sum, American cooking is deeply rooted in radical regional and cultural distinctions, which - due to a variety of forces such as settler-native trade, a sense of European cultural superiority, and the reliance on slavery - grew into the "melting pot" style cuisine America is known for today. There was reliance on the Indigenous people as well as the African slaves out

\footnotetext{
${ }^{80}$ Tobias, "Early American Cookbooks," 3.

${ }^{81}$ Randolph, The Virginia Housewife xi.

${ }^{82}$ Bryan, The Kentucky Housewife, vii.

${ }^{83}$ Theophano, Eat My Words, 238.
} 
of necessity - economically, and at times for basic survival - which inadvertently led to the acculturation of these subjugated cultures into the broader identity. Women, too, were restricted in almost every way, but cooking was a domain in which they were relied on and could thrive. Indigenous peoples were subjected to "civilizing" missionary efforts to replace their traditional ways of life with European lifestyles, and African slaves were forced to leave their homelands' cultures behind. The irony is, in spite of these prevalent racist, sexist attitudes and attempts to assimilate, these traditions and techniques are irreversibly entrenched in the nations' food. From the annual Thanksgiving feast to classic Southern barbeque, the cultures of Indigenous Americans and African slaves are present in many forms. American food history is, at its core, a story of oppressed people - women, and cultural minorities - expressing autonomy in the face of social restriction. 


\section{Bibliography}

Abbott, Elizabeth. Sugar: A Bittersweet History. Toronto: The Penguin Group, 2008.

Baltimore, J. M. "In the Prime of the Buffalo." In Overland monthly and Out West magazine, November 1889.

Beecher, Catharine Esther. Miss Beecher's Domestic Receipt Book. New York: Harper \& Brothers, 1846.

Bryan, Mrs. Lettice. The Kentucky Housewife. Cincinnati: Shepard \& Stearns, 1839.

Burris, Evadene A. "Frontier Food." In Minnesota History 14, 378-392. St. Paul: Minnesota Historical Society Press, 1933.

Calloway, Colin G. New Worlds for All. Baltimore: The John Hopkins University Press, 2013.

Egerton, John. Southern Food: At Home, on the Road, in History. Chapel Hill: The University of North Carolina Press.

Foner, Eric. Give Me Liberty! An American History. New York: W. W. Norton \& Company, 2008.

Leslie, Eliza. Miss Leslie’s New Cookery Book. Philadelphia: T. B. Peterson and Brothers, 1857.

Longone, Jan. "Amelia Simmons and the First American Cookbook." In American Bookseller, August 12, 1996.

McClure, David. Diary of David McClure, doctor of divinity. New York: The Knickerbocker Press, 1899.

McWilliams, James E. A Revolution in Eating: How the Quest for Food Shaped America. New York: Columbia University Press, 2005.

Orr, Mrs. N. De Witt's Connecticut Cook Book and Housekeeper's Assistant. New York: Robert M. De Witt, 1871.

Owen, Mrs. T. J. V. Mrs. Owen's Illinois Cook Book. Springfield: John H. Johnson, 1871.

Parloa, Maria. The Appledore Cook Book. Boston: Andrew F. Graves, 1880.

Randolph, Mary. The Virginia Housewife: or, Methodical Cook. Baltimore: John Plaskitt, 1836.

Rebora, Giovanni. Culture of the Fork. New York: Columbia University Press, 2001. 
Rutledge, Sarah. The Carolina Housewife: or, House and Home. Charleston: W. R. Babcock, 1851.

Schlissel, Lillian. Women's Diaries of the Westward Journey. New York: Schocken Books, 2004.

Simmons, Amelia. American Cookery. Albany: Charles R. \& George Webster, 1796.

Theophano, Janet. Eat My Words: Reading Women's Lives through the Cookbooks They Wrote. New York: Palgrave, 2002.

Tobias, Steven M. "Early American Cookbooks as Cultural Artifacts.” In Papers on Language \& Literature 34.1, 3. Carbondale: Southern Illinois University Press. 